\title{
Études/Inuit/Studies
}

\section{Barnabas Peryouar (1924-2004)}

Volume 28, numéro 2, 2004

Espaces-Lieux-Noms

Spaces-Places-Names

URI : https://id.erudit.org/iderudit/013218ar

DOI : https://doi.org/10.7202/013218ar

Aller au sommaire du numéro

\section{Éditeur(s)}

Association Inuksiutiit Katimajiit Inc.

Centre interuniversitaire d'études et de recherches autochtones (CIÉRA)

\section{ISSN}

0701-1008 (imprimé)

1708-5268 (numérique)

Découvrir la revue

Citer ce document

(2004). Barnabas Peryouar (1924-2004). Études/Inuit/Studies, 28(2), 266-267.

https://doi.org/10.7202/013218ar d'utilisation que vous pouvez consulter en ligne.

https://apropos.erudit.org/fr/usagers/politique-dutilisation/ 


\section{Barnabas Peryouar}

\section{(1924-2004)}

Barnabas Peryouar died on October 31, 2004. He was 80. A respected Elder, Peryouar was widely known for his traditional knowledge especially of Inuit culture and heritage and self-government. Born at Qikiqtauyaq in 1924, he was named after his biological mother and/or his adoptive mother's sister (Sarah Peryouar, pers. comm. 2005). The name Peryouar means "something that is thought greatly of" (Alexina Kublu, pers. comm. 2004) or one who is held in high esteem. To Inuit he was known as "the great one." He was a Qairnirmiuq who lived a traditional life mostly to the south and west of Baker Lake. In 1943, he moved to the small settlement of Baker Lake and married Inukpaluk and together they had 12 children. He lived through the famine in the 1950s. Peryouar was a devout Christian, member of Qilautimiut, the Elders' Society, and active member of the community.

Commissioner of Nunavut Peter Irniq (pers. comm. 2005) said "I can say from my heart that Barnabas was part of that foundation when we were beginning to discuss Nunavut Political Development in the early 1970s. He knew his culture, he knew where Inuit came from, how hard Inuit worked to survive and most of all, he knew where he wanted to go. This is where he will be missed for his great wisdom and knowledge about Inuit history, culture and language and particularly Inuit Qaujimajatuqangit."

In 1979, Peryouar and his wife Inukpaluk were two of many Inuit of Baker Lake who took the federal government to court over aboriginal rights and protection from mining in the area. He became involved in land claims negotiations with the Inuit Tapirisat of Canada and from 1982-1987 he represented Baker Lake when he sat on the board of the Keewatin Inuit Association.

He was respected for his Inuit Qaujimajatuqangit or traditional knowledge, outgoing personality and willingness to share his knowledge with others. In 1958, Peryouar started working with biologists for the Canadian Wildlife Service. He sat on various boards for caribou management, heritage rivers, historic sites and local museum. A founding Trustee of the Inuit Heritage Trust and former Vice-President, he was first appointed to the board by Nunavut Tunngavik Incorporated in 1994. He was re-appointed in 1996 and again in 1999; his term with the Inuit Heritage Trust ended in 2001. He assisted on archaeological projects in the Baker Lake area including: Aberdeen Lake (1991), Piqqiq (1993), Itimnik (1994) and Qamanaarjuk (1995) on the Kazan River. Peryouar would enthusiastically interpret the sites, teaching the archaeologists and youth on-site. Heritage was important to him and he expressed his wish for a museum in Baker Lake. His vision would be realized in 1998 with the opening of the Inuit Heritage Centre. Peryouar contributed to the oral history research of Baker Lake and emphasized the need to also record knowledge in the written form. 
In 1999, he was awarded the Elders Recognition Award for his contributions by the Inuit Heritage Trust. In 2000 he was awarded the Commissioner's Award for his contributions to Inuit Qaujimajatuqangit. From 2000-2002 he was appointed to the Maligarnit Qimirrujiit, the Nunavut Law Review Commission by the Nunavut Government. Barnabas Peryouar will be greatly missed. (Source: Deborah Kigjugalik Webster) 